\title{
Üniversitelerde Muhasebe Öğretim Elemanlarının, Muhasebe Eğitimi Hakkındaki Görüşleri Üzerine Bir Araştırma: Güneydoğu Anadolu Bölgesi Örneği *
}

\author{
Yasemin EZIN ${ }^{* *}$ \\ Abdulkadir BİLEN ${ }^{* * *}$ \\ Ramazan ASLAN ${ }^{* * * *}$ \\ Salahattin ALTUNDAĞ ${ }^{* * * * *}$
}

\section{ÖZET}

Bu çalışma akademisyenlerin bakış açısıyla, üniversitelerdeki muhasebe eğitim sürecindeki noksanlıklarl, eğitimde yer alması gereken ders içeriklerini, ders ortamında kullanılan yöntem ve araçları, üniversitelerdeki çalışma koşulları gibi faktörlerin araştırılması ile eğitim sistemindeki ihtiyaçları belirlemek amaçlı yapılmıştır. Türkiye'de lisans ve ön lisans programlarında muhasebe eğitimi veren 1463 akademisyen yer almaktadır. Bu rakam Güneydoğu Anadolu bölgesinde faaliyet gösteren üniversitelerde 34 ön lisans, 88 lisans olmak üzere 122 ögretim elemanı olarak karşımıza çıkmaktadır.

Güneydoğu Anadolu bölgesinde görev yapan ve muhasebe eğitimi veren 48 akademisyen üzerinde gerçekleştirilen anket çalışmasında, akademisyenlerin cinsiyet, görev yeri, akademik unvan, çalışma süreleri gibi demografik özellikleri ile muhasebe ĕ̆itimi üzerindeki görüşleri incelenmiştir. Ayrıca akademisyenlerin eğitim sistemi hakkındaki öneri ve yorumlarına da çalışma sonunda yer verilmiştir.

Anahtar Kelimeler: Muhasebe Ĕ̌itimi, Akademisyen, Muhasebe.

JEL Sınıflandırması: M41, I20, I21.

\section{A Research On The Opinions Of Accounting Teachers On Accounting Education In} The University: The Case Of The Southeastern Anatolia Region

\section{ABSTRACT}

This study aims to determine, from an academic perspective, the needs of the accounting education by searching the factors such as the gaps in the accounting education process, the lesson contents that should be included in the education, the techniques and tools used in the accounting education process and the working conditions in universities. Despite having 1463 academicians teaching accounting courses in undergraduate and vocational college level in Turkey, the research is limited itself with the Southeastern Anatolia region in where 88 academicians at undergraduate level and 34 ones at college level are teaching accounting courses.

Interviewees were chosen in accordance with demographical features of academicians (gender, place of employment, academic title, working time and their opinions about accounting education) in the region. Based on that, the survey has been conducted with 48 academicians teaching accounting courses in the Southeastern Anatolian region. In addition, at the end of the study, suggestions and comments of academicians about the education system were included.

Keywords: Accounting Education, Academician, Accounting.

Jel Classification: M41, I20, I21.

\footnotetext{
* Bu makale Dicle Üniversitesi Sosyal Bilimler Enstitüsü İşletme Anabilim Dalı Doktora Tezinden çıkartılmıştır.

** Öğr. Gör. Yasemin Ezin, Adıyaman Üniversitesi, Sosyal Bilimler Meslek Yüksekokulu, yezin@adiyaman.edu.tr

*** Prof. Dr. Abdulkadir Bilen, Dicle Üniversitesi, İktisadi ve İdari Bilimler Fakültesi, abilen@dicle.edu.tr

**** Yrd.Doç.Dr.Ramazan Aslan, Adıyaman Üniversitesi, Iktisadi ve Idari Bilimler Fakültesi, ramazanaslan@adiyaman.edu.tr

***** Yrd. Doç.Dr. Salahattin Altundağ, Dicle Üniversitesi Sosyal Bilimler Meslek Yüksekokulu, saltundağ64@gmail.com
} 


\section{GíRiş}

Ülkemizde bireylerin toplum içerisinde eğitim düzeyi arttıkça, refah seviyesi yükselmekte ve yaşam kalitesi artmaktadır. Buna ilaveten hayat boyu öğrenme anlayışının oluşumu ile çalışma hayatlarında kural, yasal düzenleme ve işleyiş özelliklerinin aktarılması gerekliliği eğitimin sürekliliğini zorunlu kılmaktadır. Bu durum giderek artan eğitim talebinin ihtiyaç haline geldiğini göstermektedir.

Yükseköğretim kurumlarında muhasebe eğitiminde, eğitim sonrasında piyasaya uygun, bilgili, eğitimini tamamlamış, topluma katkı sağlayacak bireyler ortaya çıkarmak amaçlanmaktadır. Bu amaç doğrultusunda hedeflenen çıktıların kalitesi, muhasebe eğitiminde bulunan taraflar ile doğrudan ilişkilidir. Muhasebe eğitiminde yer alan temel unsurlar; eğitici, eğitimi alanlar ve diğer ilgili kurum veya kuruluşlar olarak belirlenmiştir (Yücenurşen vd., 2016:298).

$\mathrm{Bu}$ çalışma muhasebe eğitiminin temel unsurlarından biri olan eğiticilerin, yani akademisyenlerin üzerinde yapılmıştır. Araştırma, Güneydoğu Anadolu bölgesinde bulunan Adıyaman, Batman, Diyarbakır, Gaziantep, Şanlıurfa, Kilis, Mardin, Siirt ve Şırnak illerindeki üniversiteleri kapsamaktadır. Çalışma lisansta muhasebe ve finansman anabilim dalı ve ön lisansta muhasebe vergi uygulamaları programlarında görev yapan öğretim elemanları ile sınırlandırılmıştır. Akademisyenlerin muhasebe eğitimine yönelik görüşlerinin analizi için ise SPSS23 programından yararlanılmıştır.

\section{YÜKSEKÖĞRETIM KURUMLARINDA MUHASEBE EĞİTIMİ}

Muhasebe eğitimi meslek mensup adaylarının mesleğin gerektirdiği işlevselliğe sahip mesleki bilgi donanımı yanında kişisel nitelikler ve etik değerlere sahip bireyler yetiştirmelidir (Alkan, 2015:139). Bu nedenle eğitim ortaöğretim kurumlarında başlayan, yükseköğrenim ile geliştirilen ve mesleki hayatta da sürekli öğrenmeyi gereksinim haline getiren bir aday yaratması beklenmektedir. Ülkemizde Yükseköğretim kurumlarında verilen muhasebe eğitimi üç düzeyde karşımıza çıkmaktadır.

Meslek Yüksekokullarında Muhasebe Eğitimi: Ön lisans eğitimi olarak yükseköğretim programlarında yer alan Meslek Yüksekokullarında eğitim süresi iki yıl olup, toplamda dört yarıyllık eğitim-öğretim döneminden oluşmaktadır (YÖK, 2002). Muhasebe dersleri bu dört dönem içerisinde seçmeli ve zorunlu olarak verilmektedir. Bu bölümlerin amacı piyasanın ihtiyacı olan ön muhasebe elemanı ihtiyaçlarını karşılamak olup, bu bölümlerde eğitim gören öğrenciler eğitimlerini örgün veya açıktan/uzaktan eğitim yolları ile kariyer gelişimlerini devam ettirebilmektedir (Özdemir, 2010:15).

Lisans Düzeyinde Muhasebe Eğitimi: Genel olarak lisansta muhasebe eğitimi, İktisadi ve İdari Bilimler Fakültesindeki bölümlerde üç ya da dört ylllık süreçten oluşmaktadır. Bu 
bölümlerde muhasebe eğitimi sonrası meslek mensubu adaylarını yetiştirmek ön plana çıkmaktadır.

Yüksek Lisans ve Doktora Düzeyinde Muhasebe Ĕgitimi: Branşta uzmanlaşmak için yapılan lisans sonrası eğitimleri kapsamaktadır. Bu düzeyde bulunan öğrenciler iki veya dört dönem içerisinde ders aşaması ve tez çalışmasından oluşmaktadır. Doktora en yüksek eğitim seviyesi olup muhasebe bilimine katkı sağlayan çalışmaları içermektedir.

Meslek yüksekokulları, lisans ve lisansüstü programlarda eğitim sisteminde her üniversitenin düzenlemiş olduğu birbirinden farklı ders planları ve ders içerikleri bulunmaktadır (Gücenme ve Arsoy, 2006:15). Verilen muhasebe derslerinin aynı bölümlerde farklılık arz etmesi üniversitelerden mezun olanlar arasında da farklılıklara neden olmaktadır.

Günümüzde muhasebe eğitiminde, küresel boyutta ilerlemek için belirli bir standart oluşturma ihtiyacı doğmuştur. Bu nedenle Uluslararası Muhasebe Eğitim Standartları Kurulu (IAESB) kurulu, Uluslararası Muhasebeciler Federasyonu (IFAC) tarafindan oluşturulmuştur (IFAC,2016). Bu kurulun ortaya koyduğu standartlardan ilk dördü meslek mensubu adaylarının eğitimine yönelik, diğerleri eğitim sonrasına, sekizinci standart ise denetime yönelik hazırlanmıştır (Can ve Demirci, 2016:340). Uluslararası bir boyut taşıyan sekiz standarttın eğitim sistemimizde de yapılandırılması ülke gelişimimize büyük katkı sağlayacaktır. Böyle bir yapılanma doğrultusunda ülkemiz eğitim sisteminde uluslararası muhasebe eğitim standartları sayesinde küresel piyasalarda ortak bir muhasebe dili oluşturulmuş olacaktır. Aynı zamanda akreditasyon ve mesleki eğitimin sürekliliğine yönelik olarak eğitim içeriği sürekli yenilenebilir sisteme kavuşacaktır (Tazegül ve Karabayır, 2015:72).

\section{LITERATÜR TARAMASI}

Arsoy ve arkadaşları (2014), 63 Akademisyen ve 230 muhasebe meslek mensubu üzerinde yaptıkları çalışmada muhasebe meslek mensubu olabilmenin temel özelliklerini belirlerken araştırmaya katılanların deneyim ve bilgi birikimlerinden yaralanmışlardır. Her iki tarafinda muhasebe eğitimi için içerik ve yöntem konusunda farklı düşündükleri yönünde bulgular elde edilmiştir.

Doğan ve Çürük (2001), öğretim üyelerine yönelik olarak muhasebe ders ve içeriklerinin tespiti konusunda yaptıkları çalışmada öğretim elemanlarının \%82 çoğunluğunun program hazırlarken uluslararası gelişimleri ve yurtdışı eğitim programlarını dikkate aldıkları, geri kalan öğretim elemanlarının ise sadece \%18 inin piyasa ihtiyacına yönelik derslerini belirlediklerini tespit etmişlerdir. 2002 yılında yapmış oldukları çalışmada işletmelerin üniversite ile işbirliğine olumlu baktıklarını tespit etmişlerdir. Bu çalışmalarında da akademisyenler tarafından \% 91 gibi bir çoğunluğun muhasebe ders müfredatı oluşturulmasında sanayi ile işbirliğine taraftar oldukları yönünde benzer sonuçlar elde etmişlerdir. 
Çelenk ve arkadaşları (2010) Marmara Üniversitesinde işletme bölümünde 103 öğrenci üzerinde, öğrencilerin muhasebe dersini veren öğretim elemanlarına ve muhasebe mesleğine bakış açılarını tespit etmek için anket çalışması yapmışlardır. Elde edilen bulgularda muhasebe eğitiminde derslerin alınmasında dersi veren hocaların önemli bir etken olduğu, bununla birlikte meslek olarak iş bulma imkânına sahip kariyerli bir meslek olduğu ortaya çıkmıştır.

Erol ve Erkan (2008), Çanakkale Onsekiz Mart Üniversitesi Biga İktisadi ve İdari Bilimler Fakültesinde toplamda 219 öğrenciye anket çalışması uygulamışlardır. Araştırma sonuçları incelendiğinde, öğretim elemanların ders işleme tekniklerinin öğrencilerin ders başarılarını etkilediği tespit edilmiştir. Ayrıca Eğitim kurumunun fiziksel koşullarının yetersiz olmasından kaynaklı benzer şekilde muhasebe derslerindeki başarılarını olumsuz etkilediği bulguları elde edilmiştir.

Eleren ve Kayahan (2007), Afyon Kocatepe Üniversitesi Meslek Yüksekokulundan 150 öğrenci üzerinde anket uygulaması yapmışlardır. Elde ettikleri sonuçlara göre öğrencilerin muhasebe bölümünü tercih sebepleri arasında iş bulma olanağını ilk neden olarak göstermişlerdir. Ayrıca muhasebe eğitiminde öğrenmenin büyük çoğunluğunun öğretim elemanına bağlı olduğunu tespit etmişlerdir.

Gençtürk ve Bağc1 (2005), MYO' lar da eğitim veren öğretim elemanları üzerine muhasebe eğitimindeki sorunların tespiti için anket uygulaması gerçekleştirmiş, elde edilen bulgular sonucunda ticaret liselerinden sınavsız üniversiteye geçiş olması sebebiyle öğrencilerin yeterli düzeyde bilgiye sahip olmaması başarı düzeyini düşürmekte, aynı zamanda teknik olanakların sağlanamaması temel sorun olarak belirlenmiş̧ir.

\section{GÜNEYDOĞU ANADOLU BÖLGESINDE MUHASEBE ÖĞRETIM ELEMANLARININ DURUMU}

Yükseköğretim kurumları içerisinde 109 devlet, 76 vakıf olmak üzere toplamda 185 üniversite bulunmaktadır. Meslek yüksekokullarına bakıldığında ise 827 devlet, 105 vakıf, 8 vakıf meslek yüksekokulu olmak üzere 940 tane ön lisans eğitim veren kuruluş yer almaktadır (YÖK, 2017). Bu üniversitelerimizde mevcut lisans ve ön lisans programlarında birçok bölüm/program farklı alanlarda eğitim vermektedir. Muhasebe alanına yönelik eğitim veren üniversitelerin öğretim elemanları incelendiğinde Tablo 1 de yer alan bilgiler elde edilmiştir. 
Tablo 1. Ön lisans/ Lisans Eğitimi Veren Yükseköğretim Kurumlarında Muhasebe Alanında Görevli Öğretim Elemanlarının Sayıları, 2015-2016

\begin{tabular}{|c|c|c|c|c|c|c|c|c|}
\hline Birimler & Prof. & Doçent & Yrd.Doç. & Öğr.Grv. & Okutman & Uzman & Ar.Gör. & Toplam \\
\hline $\begin{array}{c}\text { Muhasebe ve } \\
\text { Vergi } \\
\text { (Önlisans) }\end{array}$ & 5 & 8 & 62 & 599 & 9 & 7 & 9 & 699 \\
\hline $\begin{array}{c}\text { Muhasebe ve } \\
\text { vergi (Lisans) }\end{array}$ & 157 & 146 & 227 & 28 & & 6 & 200 & 764 \\
\hline Toplam & 162 & 154 & 289 & 627 & 9 & 13 & 209 & $\mathbf{1 4 6 3}$ \\
\hline
\end{tabular}

Kaynak: YÖK, Yükseköğretim İstatistikleri, https://istatistik.yok.gov.tr/, 2017

Yukarıdaki tabloda da görüldüğü üzere ön lisans programlarında çoğunluğu öğretim görevlisinden oluşan 699 öğretim elemanı bulunmaktadır. Lisans programlarına bakıldığında ise unvanlı öğreticilerin birbirine yakın dağılım gösterdiği toplamda 764 öğretim elemanın yer aldığı görülmektedir. Yükseköğretim kurumlarında muhasebe ve vergi alanlarında eğitim veren akademik yapı altında toplamda 1463 akademisyen bulunmaktadır.

Bölgesel olarak çalışma ele alındığında ise Güneydoğu Anadolu Bölgesinde yer alan üniversitelerimiz Adıyaman, Batman, Diyarbakır, Gaziantep, Şanlıurfa, Kilis, Mardin, Siirt ve Şırnak illerini kapsamaktadır. Bu illerde toplamda 9 devlet 2 vakıf üniversitesi olmak üzere 11 üniversite yer almaktadır. Ülke geneline bakıldığında 185 üniversitenin sadece \%5,4 oranı bu bölgede faaliyet göstermektedir.

Tablo 2. Güneydoğu Anadolu Bölgesinde Faaliyet Gösteren Üniversiteler

\begin{tabular}{|lll|}
\hline Üniversiteler & Bulunduğu İl & Türü \\
\hline Adıaman Üniversitesi & Adıyaman & Devlet \\
\hline Batman Üniversitesi & Batman & Devlet \\
\hline Dicle Üniversitesi & Diyarbakır & Devlet \\
\hline Gaziantep Üniversitesi & Gaziantep & Devlet \\
\hline Hasan Kalyoncu Üniversitesi & Gaziantep & Vakıf \\
\hline Sanko Üniversitesi & Gaziantep & Vakıf \\
\hline Harran Üniversitesi & Şanlıurfa & Devlet \\
\hline Kilis 7 Aralık Üniversitesi & Kilis & Devlet \\
\hline Mardin Artuklu Üniversitesi & Mardin & Devlet \\
\hline Siirt Üniversitesi & Siirt & Devlet \\
\hline Şırnak Üniversitesi & Şırnak & Devlet \\
\hline
\end{tabular}

Kaynak: YOK, Yükseköğretim İstatistikleri, 2016

Yukardaki tabloda görüldügü gibi Gaziantep ilinde 3 üniversite olup, diğer illerde birer tane üniversite mevcuttur. Bu üniversitelerde yer alan lisans ve ön lisans akademisyen sayıları ayrı ayrı ele alındığında ise lisansta muhasebe ve finansman anabilim dalı, ön lisansta muhasebe ve vergi uygulamaları programları incelenmiştir. 
Tablo 3. Güneydoğu Anadolu Bölgesinde Yer Alan Üniversitelerdeki Muhasebe ve Finansman Anabilim Dalı Akademisyen Sayısı

\begin{tabular}{|l|c|c|c|c|c|c|}
\hline \multicolumn{1}{|c|}{ Üniversite } & Profesör & Doçent & $\begin{array}{c}\text { Yardımcı } \\
\text { Doçent }\end{array}$ & $\begin{array}{c}\text { Öğretim } \\
\text { Görevlisi }\end{array}$ & $\begin{array}{c}\text { Araştırma } \\
\text { Görevlisi }\end{array}$ & $\begin{array}{c}\text { Toplam } \\
\text { Akademisyen }\end{array}$ \\
\hline Adıyaman & 0 & 2 & 0 & 1 & 3 & 6 \\
\hline Batman & 0 & 1 & 0 & 1 & 1 & 3 \\
\hline Dicle & 1 & 0 & 0 & 1 & 3 & 5 \\
\hline Gaziantep & 1 & 1 & 1 & 0 & 1 & 4 \\
\hline Harran & 0 & 0 & 2 & 0 & 0 & 2 \\
\hline Kilis & 0 & 0 & 1 & 0 & 0 & 4 \\
\hline Artuklu & 0 & 1 & 2 & 1 & 0 & 2 \\
\hline Siirt & 0 & 0 & 1 & 0 & 1 & 6 \\
\hline Şırnak & 1 & 0 & 3 & 1 & 1 & 34 \\
\hline Toplam & 3 & 5 & 11 & 5 & 10 & \\
\hline
\end{tabular}

Kaynak: YOK, Yükseköğretim İstatistikleri, 2017

Güneydoğu Anadolu bölgesinde muhasebe ve finansman anabilim dalının yer aldığı 7 üniversite bulunmaktadır. Bu üniversitelerdeki akademisyen sayısının 3 profesör, 5 doçent, 11 yardımcı doçent, 5 öğretim görevlisi, 10 araştırma görevlisi olmak üzere toplamda 34 olduğu görülmektedir. Ülkemizde lisans programları içerisinde muhasebe öğreticilerin sadece \%4,45'i kadarı bu bölge içerisinde görev yapmakta olduğu tespit edilmiştir.

Tablo 4. Güneydoğu Anadolu Bölgesinde Yer Alan Meslek Yüksekokulu Muhasebe ve Vergi Uygulamaları Programlarındaki Akademisyen Sayısı

\begin{tabular}{|l|c|c|}
\hline \multicolumn{1}{|c|}{ Üniversiteler } & MYO Sayısı & Akademisyen Sayısı \\
\hline Adıyaman Üniversitesi & 6 & 10 \\
\hline Batman Üniversitesi & 4 & 2 \\
\hline Dicle Üniversitesi & 10 & 22 \\
\hline Gaziantep Üniversitesi & 10 & 18 \\
\hline Harran Üniversitesi & 11 & 8 \\
\hline Şırnak Üniversitesi & 4 & 7 \\
\hline Mardin Artuklu Üniversitesi & 6 & 5 \\
\hline Kilis 7 Aralık Üniversitesi & 2 & $\mathbf{8 8}$ \\
\hline Siirt Üniversitesi & 5 & 4 \\
\hline TOPLAM & $\mathbf{5 8}$ & \\
\hline
\end{tabular}

Kaynak: Üniversitelerin resmi internet sayfalarındaki bilgilerden yararlanılmıştır,(2016)

Türkiye'de 94 üniversiteye bağlı toplam 274 meslek yüksekokulunda muhasebe ve vergi uygulamaları bölümü bulunmaktadır (Alkan, 2015:144). Yükseköğretim kurumlarında yer alan lisans programlarından sonra, ülke genelinde daha yaygın olan meslek yüksekokullarındaki akademisyen sayıları ele alınmıştır. Yukarıdaki tabloda da görüldüğü 
üzere 9 üniversiteye bağlı toplamda 58 meslek yüksekokulu bulunmaktadır. Ancak sadece 24 tanesinde muhasebe ve vergi uygulamaları bölümü mevcut olup toplamda 88 akademisyen görev yapmaktadır.

\section{5. ÜNIVERSITELERDE MUHASEBE ÖĞRETIM ELEMANLARININ, MUHASEBE EĞITTIMI HAKKINDAKİ GÖRÜŞLERI ÜZERINE BİR ARAŞTIRMA: GÜNEYDOĞU ANADOLU BÖLGESI ÖRNEĞİ}

\subsection{Araştırmanın Amacı}

$\mathrm{Bu}$ çalışmada; üniversitelerde lisans bölümleri ve ön lisans programlarında uygulanan muhasebe eğitiminin, akademisyenlerin görüşleri doğrultusunda etkinliği araştırılmıştır. Bu amaç doğrultusunda, üniversitelerdeki muhasebe eğitim sürecindeki noksanlıklar, eğitimde yer alması gereken ders içerikleri, ders ortamında kullanılan yöntem ve araçlar, üniversitelerdeki çalışma koşulları gibi birçok yönden eğitim sistemindeki ihtiyaçları belirlemek ve öneriler getirmektir.

\subsection{Araştırmanın Kapsamı ve Kısıtları}

$\mathrm{Bu}$ araştırmanın evrenini Güneydoğu Anadolu Bölgesinde yer alan devlet ve vakıf üniversitelerinde lisans ve ön lisans programlarında muhasebe alanında eğitim veren akademisyenler oluşturmaktadır. Çalışma lisansta muhasebe ve finansman anabilim dalı ve ön lisansta muhasebe vergi uygulamaları programlarında görev yapan öğretim elemanları ile sınırlandırılmıştır.

Araştırmanın örneklemini Güneydoğu Anadolu Bölgesinde yer alan 11 üniversite içerisinde lisans ve ön lisans programlarında muhasebe eğitimi veren 122 akademisyen oluşturmaktadır. Veri toplama aracı olarak anket formu kullanılmıştır. Çalışma kapsamında bulunan akademisyenlere mail yolu ile ulaşılmış olup, 54 tanesinden geri dönüş alınmıştır. Bunlardan ise 6'sı geçersiz kabul edildiğinden 48'i üzerinde analiz ve değerlendirme yapılmıştır.

\subsection{Araştırmanın Yöntemi ve Kapsamı}

Araştırmada, Sayın ve diğerleri (2005) tarafından kullanılmış 9 boyutlu anket formundan yararlanılmış ve güncellemeler yapılarak çalışma tekrardan geliştirilip, düzenlenmiştir. Düzenlenen anket formu iki bölümden oluşmaktadır. Birinci bölümde, akademisyenlerin demografik özelliklerine yönelik 5 soru yer almakta olup, ayrıca uygulamalı derslerde uygulanan muhasebe paket programlarının tespitine yönelik açık uçlu 1 soru bulunmaktadır. İkinci bölümde ise akademisyenlerin üniversitelerdeki muhasebe eğitiminin etkinliğine yönelik bakış açılarını belirlemeye yönelik toplamda 24 sorudan oluşan anket formu oluşturulmuştur. İlk 23 soru hazırlanırken 5'li Likert ölçeğinden faydalanılmıştır. 24. soruda ise açık uçlu bir soru sorularak akademisyenlerin üniversitelerdeki lisans ve Meslek Yüksekokullarındaki muhasebe eğitimi ile ilgili görüşleri ve düşünceleri belirlenmeye 
çalışılmıştır. İlk 23 soru 5 boyut olarak ele alınmıştır. Boyutlar, "2-3-4-5" numaralı ifadeler müfredat, "6-7-8-9-10" numaralı ifadeler anlatım teknikleri, "1-12-13-14-16" numaral1 ifadeler eğitim çıktıları, "11-17-18-19-20" numaralı ifadeler eğitim ortamı ve "21-22-23” numaralı ifadeler ise meslek mensupları hakkında akademisyen görüşlerinin tespitine yöneliktir.

Çalışmada kullanılan 5'li Likert ölçeği “Kesinlikle Katılmıyorum”, "Katılmıyorum”, "Kararsızım”, “Katılıyorum” ve "Kesinlikle Katılıyorum” ifadelerinden oluşmakta ve ölçek puanlamas1 yapılırken verilen cevaplar "Kesinlikle Katılmıyorum" ifadesinden "Kesinlikle Katılıyorum” ifadesine doğru 1-2-3-4-5 şeklinde kodlanmıştır. Ayrıca ifadelerin ortalamalarının yorumlanmasında ise; "1-1,80" arasındaki ortalama değerlerin "Kesinlikle Katılmiyorum", "1,81-2,60" arasinda bulunanların "Katılmiyorum", "2,61-3,40” arasındakileri "Kararsızım", "3,41-4.20" arasındakilerin "Katıliyorum" ve "4,21-5" arasında yer alanların ise "Kesinlikle Katılıyorum” derecesinde değer taşıdığı kabul edilmiştir. Düzeylerin yer aldığı bu aralıklar, seçeneklere verilen en düşük değer olan 1 ile en yüksek değer olan 5 arasındaki seri genişliğinin seçenek sayısına bölünmesi ile elde edilmiştir. Anket sonuçları ise SPSS 23 programından yararlanılarak bulguların değerlendirilmesinde bağımsız t testi ve tek yönlü varyans analizi (Anova) kullanılmıştır.

\subsection{Bulgular}

Çalışmanın birinci bölümünde ankete katılan akademisyenlerin demografik özellikleri incelenmiştir. Cinsiyet, görev yeri, çalışma süreleri, akademik unvan ve eğitim durumlarına göre araştırmaya katılanların özellikleri aşağıdaki tabloda ayrıntılı olarak verilmiştir.

Tablo 5. Akademisyenlerin Demografik Özellikleri

\begin{tabular}{|l|l|l|}
\hline \multicolumn{2}{|l|}{ Sayı } & Oran(\%) \\
\hline Değişkenler & 20 & 41,7 \\
\hline Cinsiyet & 28 & 58,3 \\
\hline Erkek & 24 & 50,0 \\
\hline Görev Yeri & 24 & 50,0 \\
\hline Fakülte & \multicolumn{2}{|l|}{} \\
\hline Meslek Yüksekokulu & 15 & 31,3 \\
\hline Çalışma süresi & 17 & 35,4 \\
\hline $1-5$ & 16 & 33,3 \\
\hline $6-10$ & \multicolumn{2}{|l|}{} \\
\hline 11 ve üstü & 5 & 10,4 \\
\hline Akademik Ünvan & 3 & 6,3 \\
\hline Profesör & 36 & 75,0 \\
\hline Doçent & 4 & 8,3 \\
\hline Öğr. Grv. & & \\
\hline Arş. Grv & & \\
\hline &
\end{tabular}




\begin{tabular}{|l|l|l|}
\hline \multicolumn{2}{|c|}{ Ĕ̈itim Durumu } & \multicolumn{2}{|l|}{} \\
\hline Lisans & 2 & 4,2 \\
\hline Yüksek Lisans & 15 & 31,3 \\
\hline Doktora & 31 & 64,6 \\
\hline
\end{tabular}

Çalışmaya katılan akademisyenlerin \%41,7'si bayan, \%58,3’ü erkeklerden oluşturmaktadır. Görev yerleri değişkeni incelendiğinde katılımcıların yarısı fakültelerde diğer yarısı meslek yüksekokullarında görev yapmaktadır. Çalışma sürelerinde 1 ile 5 yıl arasında görev yapmış olanların oranı \%31,3 iken 6-11 ve üstü görev süresi olanların toplam oranı \%68,7 olduğu görülmektedir. Akademisyenlerin unvan sahipliliğinde ise genel olarak katılımcıların öğretim görevlisi olduğu tespit edilmiştir. Çalışmada akademik unvan sahibi sadece 8 akademisyen yer almaktadır. Ancak eğitim durumlarına bakıldığında \%64,6'sının doktora derecesine sahip olduğu görülmekledir.

Ayrıca bu bölümde akademisyenlerin uygulamalı bilgisayarlı muhasebe derslerinde kullanmış olduğu paket programların tespitine yönelik sorulan soruya 21 kişi cevap vermiş olup, diğer katılımcılar bilgi vermemiştir. Elde edilen verilerde, Orka (2), Eta (6), Logo(3), Zirve(1), Mikro(2), Luca(6), Vega Paket(1) programlarının üniversite eğitiminde yer aldığ1 görülmektedir. Eğitim sisteminde yer alan bu programlarının, piyasada kullanılan programlara göre güncellenmesi halinde piyasa ile uyum sağlanabilecektir.

\subsection{Güvenilirlik Testi}

Anketler SPSS 23 programına girildikten sonra öncelikli olarak normallik ve güvenilirlik testileri uygulanmıştır. Normallik testinde Kolmogorov-Smirnov testinden yararlanılmıştır. $\mathrm{Bu}$ yöntem hipotez testlerinin normallik varsayımını belirleyen ve yaygın olarak kabul gören bir yöntemdir. Kolmogorov-Smirnov testi sonucunda $\mathrm{z}$ değeri ve anlamlılıklarda p>0.05 değeri elde edildiğinde dağılımın normal dağılımdan anlamlı bir farklılık yaratmadığı yorumu yapılır (Ortar,2017).

Bir diğer test ise ölçeğin güvenilirliğinin tespitine yöneliktir. Güvenilirlik testi olarak bilinen bu yöntemde önemli olan cronbach Alpha $(\alpha)$ değeridir (Tavakol ve Dennick, 2011:54). Eğer cronbach's alpha katsayısı $0.60 \leq \alpha<0.80$ aralığı ölçeğin oldukça güvenilir olduğunu yorumu yapılabilir (Özdamar, 1999).

Ortalama müfredat, anlatım teknikleri, eğitim çıktıları ve eğitim ortamına ait ifadelerin değerleri üzerinden hesaplanmıştır. Bu serilerin normal dağılımı Kolmogorov-Smirnov (K-S) testi ile incelenmiş, $\mathrm{z}$ istatistiği anlamlılıkları sırasıyla $0,561,0,561,0,805,1,366$ ve 0,586 olduğundan verilerin normal dağıldığı kabul edilmiştir. $\mathrm{Bu}$ sonuç doğrultusunda ölçek üzerinde faktör analizine gidilmiştir. Ölçeğin tüm soruları ve 5 alt boyutu için cronbach's alpha değerleri aşağıdaki tabloda gösterilmektedir. 
Tablo 6. Boyutları ve Alpha Değerleri Dağılım Tablosu

\begin{tabular}{|lll|}
\hline Boyutlar & İfadeler & Cronbach's alpha \\
\hline Müfredat & $2-3-4-5$ & 0,655 \\
\hline Anlatım teknikleri & $6-7-8-9-10$ & 0,646 \\
\hline Eğitim çıtııları & $1-12-13-14-16$ & 0,749 \\
\hline Eğitim Ortamı & $11-17-18-19-20$ & 0,723 \\
\hline Meslek Mensup Görüşleri & $21-22-23$ & 0,711 \\
\hline
\end{tabular}

Çalışılan ölçeğinin tüm soruları için cronbach's alpha katsayısı $\alpha=0,740$ olarak hesaplanmıştır. Boyut olarak ele alındığında ise cronbach's alpha katsayıları müfredat için $\alpha$ $=0,655$, anlatım teknikleri için $\alpha=0,646$, eğitim çıktıları $\alpha=0,749$, eğitim ortamı $\alpha=0,711$ ve meslek mensupları görüşleri $\alpha=0,723$ şeklinde tespit edilmiştir. Çıkan bu değerler çalışmanın oldukça güvenilir olduğunu göstermektedir.

\subsection{Faktör Analizi}

Sosyal bilimler alanında hipotezleri test etmek için en yaygın kullanılan yöntem $\mathrm{t}$ testidir. $\mathrm{t}$ testi, iki değişken grubun ortalamaları karşılaştırılarak aralarında istatiksel olarak anlamlı farklılık olup olmadığını belirlemeye yöneliktir (Bayram,2004:83). Bu yüzden araştırmamızda cinsiyet değişkenine göre farklılık olup olmadığını incelenmesi için bayan ve erkek değişkenine bağımsız $\mathrm{t}$ testi uygulanmıştır.

Tablo 7. Akademisyenlerin Cinsiyetlerine Göre " $\mathrm{t”}$ Testi ile Karşıllaştırılması

\begin{tabular}{lccccc}
\hline Boyut & Cinsiyet & n & Ort. & t & P \\
\hline \multirow{2}{*}{ Müfredat } & Bayan & 20 & 25 & 0,537 & 0,594 \\
& Erkek & 28 & j5 & & \\
\multirow{2}{*}{ Anlatım Teknikleri } & Bayan & 20 & 70 & 1,189 & 0,240 \\
& Erkek & 28 & 21 & & \\
\multirow{2}{*}{ Eğitim Çıktıları } & Bayan & 20 & 25 & 1,436 & 0,158 \\
\multirow{2}{*}{ Meslek Mensup Görüşleri } & Erkek & 28 & 76 & & \\
\hline \multirow{2}{*}{ Eğitim Ortamı } & Bayan & 20 & 33 & 1,569 & 0,123 \\
& Erkek & 28 & 71 & & \\
\hline
\end{tabular}

n=Katılımcı Sayısı; Ort.=Ortalama; F=Varyans Değeri; P=Anlamlılık Değeri

Cinsiyet farklılıklarına göre bayan ve erkek durumları karşılaştırıldığında boyutların tamamında istatistiksel olarak anlamlı bir ilişki olmadığı belirlenmiş ve tablodan da görüleceği gibi anlamlı bir korelasyon saptanmamıştır ( $p>0,05)$. Cinsiyet değişkeninden sonra akademisyenlerin görev yerlerine göre de t testi uygulanmış ve sonuçlar aşağıdaki gibi tablo haline getirilmiştir. 
Tablo 8. Akademisyenlerin Görev Yerlerine Göre " $\mathrm{t}$ ” Testi ile Karş1laştırılması

\begin{tabular}{llcccc}
\hline Boyut & Görev Yeri & n & Ort. & t & P \\
\hline \multirow{2}{*}{ Müfredat } & Fakülte & 24 & 3,167 & $-0,809$ & 0,423 \\
& MYO & 24 & 3,344 & & \\
\hline \multirow{2}{*}{ Anlatım Teknikleri } & Fakülte & 24 & 4,133 & $-2,363$ & 0,022 \\
& MYO & 24 & 4,450 & & \\
\hline \multirow{2}{*}{ Eğitim Çıktıları } & Fakülte & 24 & 3,444 & $-1,593$ & 0,118 \\
\hline \multirow{2}{*}{ Meslek Mensup Görüşleri } & MYO & 24 & 3,715 & & \\
\hline \multirow{2}{*}{ Ĕ̆itim Ortamı } & Fakülte & 24 & 3,625 & $-0,839$ & 0,406 \\
& MYO & 24 & 3,819 & & \\
\hline
\end{tabular}

n=Katılımcı Sayısı; Ort.=Ortalama; $\mathrm{P}=$ Anlamlılık Değeri; $\mathrm{MYO}=$ Meslek Yüksekokulu

Elde edilen verilerde beş alt boyut içerisinde sadece anlatım teknikleri boyutunda $\mathrm{p}$ değeri 0,022 olarak bulunmuştur. $\mathrm{Bu}$ değer $\mathrm{p}<0.05$ aralığında olduğundan anlamlılık düzeyinde tespit edilmiştir. Anlatım teknikleri boyutunda görev yeri ortalamalarına bakıldığında, meslek yüksekokulunda çalışan akademisyenlerin anlatım tekniklerine ait ifadelere katılım düzeyleri, fakülte çalışanlarına göre daha yüksek olduğu anlaşılmaktadır. Meslek Yüksekokullarında daha çok ara eleman yetiştirmek üzere eğitim verildiğinden uygulamaya yönelik çalışmalar daha ağırlıklıdır. Bu nedenle Meslek Yüksekokulu öğretim elemanları, fakültedeki meslektaşlarına göre daha fazla uygulama alanları üzerinde durmaktadır. Geriye kalan diğer dört boyut incelendiğinde ise istatiksel olarak $\mathrm{p}>0,05$ olduğundan anlamlı bir farklılık tespit edilmemiştir.

Diğer bir değişken olan akademisyenlerin çalışma sürelerine ilişkin değerlendirme yapabilmek için anova testi uygulanmıştır. Parametrik testlerden biri olan anova testi üç veya daha fazla bağımsız değişkenin ortalaması arasındaki farkın istatistiksel olarak anlamlı olup olmadığını ortaya koymaktadır (Bayram, 2004: 98 ).

Tablo 9. Akademisyenlerin Çalışma Süresine Göre Değişiminin Tek Yönlü Anova ile Karşılaştırılması

\begin{tabular}{|c|c|c|c|c|c|c|}
\hline Boyut & & KT. & Sd & KO & $\mathbf{F}$ & $\mathbf{P}$ \\
\hline \multirow{3}{*}{ Müfredat } & Gruplar Arası & 1,119 & 2 & 0,560 & 0,980 & ,383 \\
\hline & Gruplar İçi & 25,692 & 45 & 0,571 & & \\
\hline & Toplam & 26,811 & 47 & & & \\
\hline \multirow{3}{*}{ Anlatım Teknikleri } & Gruplar Aras1 & 1,321 & 2 & 0,660 & 3,034 & 058 \\
\hline & Gruplar İçi & 9,796 & 45 & 0,218 & & \\
\hline & Toplam & 11,117 & 47 & & & \\
\hline \multirow{3}{*}{ Eğitim Çıktıları } & Gruplar Aras1 & 1,277 & 2 & 0,639 & 1,847 & 169 \\
\hline & Gruplar İçi & 15,556 & 45 & 0,346 & & \\
\hline & Toplam & 16,833 & 47 & & & \\
\hline \multirow{3}{*}{ MeslekMensup Görüşleri } & Gruplar Arası & 1,957 & 2 & 0,979 & 1,566 & 220 \\
\hline & Gruplar İci & 28,117 & 45 & 0,625 & & \\
\hline & Toplam & 30,074 & 47 & & & \\
\hline
\end{tabular}




\begin{tabular}{lllllll}
\hline & Gruplar Arası & 2,050 & 2 & 1,025 & 1,764 &, 183 \\
Eğitim Ortamı & Gruplar İçi & 26,160 & 45 & 0,581 & & \\
& Toplam & 28,210 & 47 & & & \\
\hline
\end{tabular}

Tabloda akademisyenlerin muhasebe eğitiminin alt boyutlarına yönelik tek yönlü Anova testine bakıldığında $\mathrm{p}>0,05$ değerinde olması akademisyenlerin çalışma sürelerine göre anlamlı bir farklılık olmadığı görülmektedir. Araştırmanın bir diğer değişkeni ise muhasebe eğitiminin etkinliğine ait alt boyutlarda akademisyenlerin eğitim durumuna göre anlamlı bir farklılık olup olmadığına yöneliktir. Bu amaçla Anova testi sonucu elde edilen veriler aşağıdaki tabloda gösterilmiştir.

Tablo 10. Akademisyenlerin Eğitim Durumları Göre Değişiminin Tek Yönlü Anova ile Karşılaştırılması

\begin{tabular}{|c|c|c|c|c|c|c|}
\hline Boyut & & KT. & Sd & $\mathrm{KO}$ & $\mathrm{F}$ & $\mathrm{P}$ \\
\hline \multirow{3}{*}{ Müfredat } & Gruplar Aras1 & 1,336 & 2 & 0,668 & 1,180 & 0,317 \\
\hline & Gruplar İçi & 25,475 & 45 & 0,566 & & \\
\hline & Toplam & 26,811 & 47 & & & \\
\hline \multirow{3}{*}{ Anlatım teknikleri } & Gruplar Aras1 & 0,196 & 2 & 0,098 & 0,405 & 0,670 \\
\hline & Gruplar İçi & 10,920 & 45 & 0,243 & & \\
\hline & Toplam & 11,117 & 47 & & & \\
\hline \multirow{3}{*}{ Eğitim çıktıları } & Gruplar Arası & 0,641 & 2 & 0,321 & 0,891 & 0,417 \\
\hline & Gruplar İçi & 16,192 & 45 & 0,360 & & \\
\hline & Toplam & 16,833 & 47 & & & \\
\hline \multirow{3}{*}{ Meslekmensup görüşleri } & Gruplar Aras1 & 0,206 & 2 & 0,103 & 0,155 & 0,857 \\
\hline & Gruplar İçi & 29,868 & 45 & 0,664 & & \\
\hline & Toplam & 30,074 & 47 & & & \\
\hline \multirow{3}{*}{ Eğitim ortamı } & Gruplar Arası & 1,039 & 2 & 0,519 & 0,860 & 0,430 \\
\hline & Gruplar İçi & 27,171 & 45 & 0,604 & & \\
\hline & Toplam & 28,210 & 47 & & & \\
\hline
\end{tabular}

$\mathrm{KT}=$ Karelerin Toplamı; Sd=Serbestlik Derecesi; KO=Karelerin Ortalaması; F= Varyans Değeri; $\mathrm{P}=$ Anlamlılık Değeri

Elde edilen bilgiler doğrultusunda akademisyenlerin eğitim durumları ile muhasebe eğitimine yönelik beş boyut karşılaştırıldığında istatistik olarak $\mathrm{p}>0,05$ tespit edildiğinden anlamlı bir farklılık olmadı̆̆

Çalışma süreleri ve eğitim durumlarında anlamlı sonuçlar elde edilmemiştir. Bir diğer değişken olan akademik unvana göre ise anova testi sonucu elde edilen bulgular aşağıdaki tabloda özetlenmiştir. 
Tablo 11. Akademisyenlerin Unvanına Göre Değişiminin Tek Yönlü Anova ile Karşılaştırılması

\begin{tabular}{|c|c|c|c|c|c|c|}
\hline & & KT. & Sd & $\mathrm{KO}$ & $\mathrm{F}$ & $\mathrm{P}$ \\
\hline \multirow{3}{*}{ Müfredat } & Gruplar Arası & 1,287 & 3 & ,429 & ,739 & \multirow{3}{*}{,534 } \\
\hline & Gruplar İçi & 25,524 & 44 &, 580 & & \\
\hline & Toplam & 26,811 & 47 & & & \\
\hline \multirow{3}{*}{ Anlatım teknikleri } & Gruplar Arası & ,609 & 3 & ,203 & ,850 & \multirow{3}{*}{,474 } \\
\hline & Gruplar İçi & 10,508 & 44 & ,239 & & \\
\hline & Toplam & 11,117 & 47 & & & \\
\hline \multirow{3}{*}{ Eğitim çıktıları } & Gruplar Arası & 2,475 & 3 & ,825 & 2,529 & \multirow{3}{*}{,070 } \\
\hline & Gruplar İçi & 14,357 & 44 & ,326 & & \\
\hline & Toplam & 16,833 & 47 & & & \\
\hline \multirow{3}{*}{ Meslek mensup görüşleri } & Gruplar Arası & 9,089 & 3 & 3,030 & 6,352 & \multirow{3}{*}{,001 } \\
\hline & Gruplar İçi & 20,985 & 44 & ,477 & & \\
\hline & Toplam & 30,074 & 47 & & & \\
\hline \multirow{3}{*}{ Eğitim ortamı } & Gruplar Arası & 4,842 & 3 & 1,614 & 3,039 & \multirow{3}{*}{,039 } \\
\hline & Gruplar İçi & 23,368 & 44 & ,531 & & \\
\hline & Toplam & 28,210 & 47 & & & \\
\hline
\end{tabular}

$\mathrm{KT}=$ Karelerin Toplamı; $\mathrm{Sd}=$ Serbestlik Derecesi; $\mathrm{KO}=$ Karelerin Ortalaması; $\mathrm{F}=$ Varyans Değeri; $\mathrm{P}=$ Anlamlılık Değeri

Anova testi sonucunda elde edilen bilgiler doğrultusunda meslek mensupları görüşleri ve eğitim ortamı boyutlarında istatiksel olarak $\mathrm{p}<0.05$ anlamlılık düzeyinde çıkmıştır. Farklılık tespit edilen bu boyutların yorumlanabilmesi için Post-Hoc Scheffe testinden yararlanılmıştır. Test sonrasında elde edilen veriler doğrultusunda meslek mensupları görüşleri ve eğitim ortamı boyutların da yer alan ifadelere katılım düzeyinde profesör ve doçent, öğretim görevlisi, araştırma görevlisi unvanları arasında farklılık bulunmuş olup, doçent, öğretim görevlisi ve araştırma görevlilerinin, profesörlere göre ifadelere katılım düzeyi daha yüksek olduğu belirlenmiştir. Akademik unvanlar ilerledikçe akademisyenlerin meslek mensuplarının görüşlerine daha az önem verdiği görülmektedir. $\mathrm{Bu}$ durum akademisyenlerin kariyerlerinde ilerledikçe kendi mesleki tecrübelerini edinmelerinden kaynaklanıyor olabilir.

\subsection{Akademisyenlerin Yorum ve Önerileri}

Son olarak açık uçlu yönlendirilen soruya 48 akademisyenden sadece 11 tanesinde yorum ve öneriler belirtilmiştir. Akademisyenlerin yorum ve önerileri sınıflandırılmadan belirtilmiştir.

-Öğretim elemanlarının donanımlı olması gerektiği, sadece teknolojiyi kullanarak eğitim vermenin tek başına yeterli olmadığı düşüncesindeyim. Öğrencinin de dersleri almaya hazır olması gerekir. Bizim en büyük problemimiz orta öğretimden gelen öğrencilerin yetersiz ve ilgisiz olmasından kaynaklanmaktadır. Ayrıca sınavsız geçiş ile gelen öğrenciler derse yeterince ilgi göstermemektedirler. Üniversitelerin piyasa ile yeterli işbirliği yeterli düzeyde yapilmamaktadir. 
-Muhasebe alanında eğitim almış, deneyimli öğretim elemanlarının yetersiz olmasından dolayı zaman zaman muhasebe derslerini alan dışı hocalarımız vermek zorunda kalmaktadır. Bu durum öğrencilerin yeterli bilgiyi alamamalarına neden olmaktadır. Aynı zamanda öğretim elemanlarının da ders yükünü artırması nedeni ile performanslarını olumsuz yönde etkilemektedir. Ayrıca muhasebe bölümü ve derslerini sevdirecek, zorluk derecesini azaltacak uygulamalar yapılmalıdır.

-Sadece teori değil, pratik ve yeterli donanıma sahip laboratuvar imkânları dâhilinde bilgisayarlı muhasebe öğretilmesi faydalı olabilir. Bunun yanında öğrenci sayısının her şubede daha az olması eğitim açısından daha yararlı olacaktır.

-Özellikle meslek eğitimi alanında öğrenim gören öğrenciler yeterli motivasyona sahip olmadıklarından nitelikli mezun öğrenci yetiştirilememektedir. Üniversite sayısının ve kontenjanlarının arttırılması sebebiyle az bir netle öğrenciler yükseköğretime başlamaktadırlar. Bu da kabiliyeti bu alanlarda okumaya uygun olmayan öğrencilerin (niçin okuduğunu, mezun olunca ne yapacağını bilmeyen ve muhasebe eğitimi için gerekli bir analitik düşünceye sahip olmayan) bu okullarda yer almasına sebep olmaktadır.

-Öğrencilere bilgisayar laboratuvarında uygulamaya hakim ve mümkünse akademik unvanı da olan hocalar tarafindan piyasa ile uyumlu, günceli yansitan dersler verilmesi öğrencileri pratik hayata hazırlaması bakımından önem taşımaktadır.

-Ülkemizde birkaç öğretim kurumu dı̧̧ında amaca uygun öğretim yapılmamaktadır. Kurumsal altyapı çok yetersiz kalmaktadır. Muhasebenin yönetim bilgi sistemi ile ilişkisi kurulamaması büyük bir sorundur. Vergi ve ticaret hukuku muhasebe derslerinin temel noktası olamadığından bilgi eksikliğine sebep olmaktadır.

-Uygulamalar SMMM’ lerle işbirliği doğrultusunda staj şeklinde zorunlu olmalıdır.

-Sanal muhasebe ofisi oluşturulmalıdır.

-Sadece teoride gerçekleşen derslere mutlaka uygulamaları da eklenmelidir.

-Muhasebe dersi sadece bir ders gibi geçiştirilmemeli ileride bir meslek olarak görülmelidir.

-Eğitim için üniversitelerde yeterli imkan sağlanmamaktadır.

\section{SONUÇ}

Araştırma Güneydoğu Anadolu bölgesinde yer alan üniversitelerin İktisadi ve İdari Bilimler Fakültesi ve Meslek Yüksekokullarında İşletme ve Muhasebe ve Vergi Uygulamaları Program/Bölümlerinde görev yapan akademisyenler oluşturmaktadır. Toplam 48 akademisyene mail yolu ile anketler ulaştırılmış olup elde edilen veriler analiz tabi tutulmuştur. Bulgular doğrultusunda cinsiyet, çalışma süresi ve eğitim durumlarına göre 
çalışmada anlamlı sonuçlar elde edilmemiştir. Ancak görev yeri ve akademik unvanda anlamlı veriler bulunmuştur.

Akademisyenlerin, çalışmanın eğitim ortamı boyutunda yer alan ifadelere ait görüşlerinde, \%66,7'si öğrenci sayısının fazla olduğu, \%54,1'i çalışma ortamında yeterli sayıda öğretim üyesinin bulunmadığını belirtmiştir. Ayrıca akademisyen öneri ve yorum bölümünde de bu konu üzerinde durulmuştur. Bunun sonucu ortaya çıkan ders yükü fazlalıklarının yanında öğretim elemanlarının üzerinde idari işlerin yoğun olması, eğitimcinin ders performanslarının olumsuz olarak etkilediği sonucu ortaya çıkmaktadır. Bu nedenle muhasebe eğitim sisteminden daha çok eğitim ortamındaki fiziksel şartların iyileştirilmesine yönelik çalışmalar yapılmalıdır.

Araştırmada ayrıca akademisyenlerin, \%77,5'i ders müfredatı, \%54,2'si uygulama dersleri, \% 85,5'i seminerler gibi konuların hazırlanmasında meslek mensupları ile işbirliğinin sağlanması gerektiği görüşlerine katıldıkları tespit edilmiştir. Bu birlikteliğin sağlanabilmesi için meslek odaları ile üniversitelerin işbirliği içerisinde çalışması gereklidir.

Muhasebe eğitiminde önemli bir rolü olan akademisyenlerin, personel yetersizliğinden dolayı idari ve akademik ders yüklerinin fazlalığı, alan dışı derslerde yoğunlaşmaları sistem içerisinde olumsuzluk yaratmaktadır. Ayrıca sınıf mevcutlarının fazlalığı eğitimci açısından yorucu olmakta ve ders motivasyonunu azaltmaktadır. Üniversitelerde akademisyenlere yönelik idari işlerin azaltılması ve ayrıca ders yüklerinin alanlarına yönelik dağıtılması halinde eğitimde istenilen beklentiler sağlanabilecektir.

\section{KAYNAKLAR}

Alkan, G. (2015). “İşletmelerin Önlisans Muhasebe Eğitiminden Beklentileri: İzmir'de Bir Araştırma”. Muhasebe Bilim Dünyası Dergisi, 17(1), ss.137-158.

Arsoy, A.P.- Bora, T. - Selimoğlu, S. (2014). "Muhasebe Eğitimindeki Bilgi, Beceri Ve Eğitim Tekniklerinin Gerekliliklerine İlişkin Beklentiler: Türkiye'deki Akademisyenlere Ve Meslek Mensuplarına Yönelik Bir Araştırma”, Uluslararası Yönetim İktisat ve İşletme Dergisi, Cilt 10, Sayı 23, ss.121-136

Bayram, N. (2004). “Sosyal bilimlerde SPSS ile veri analizi”. Bursa, Ezgi Kitabevi.

Can, A. V.- Demirci, Ş. D. (2016). "Uluslararası Muhasebe Eğitim Standard1 2 Muhasebe Eğitim Programlarının İçeriğine Uyum: Sakarya Üniversitesi Örneğii”. Uluslararası Yönetim İktisat Ve İşletme Dergisi, 30, ss.319-338.

Çelenk, H.- Atmaca M.- Horasan, E. (2010). "Marmara Üniversitesi'nde Muhasebe Eğitimi Alan Öğrencilerin Muhasebe Alanına Bakış Açılarının Değerlendirilmesine Yönelik Bir Araştırma”. Marmara Üniversitesi Sosyal Bilimler Dergisi (1), ss.159-171. 
Çürük, T. - Doğan, Z. (2002). "Muhasebe Ders ve İçeriklerinin Verilme Düzeyleri Konusunda İşletmelerin Üniversitelerden Taleplerinin Tespitine İlişkin Bir Araştırma”. Dokuz Eylül Üniversitesi İİB Dergisi, 17(1), ss.107-126.

Doğan, Z.- Çürük, T. (2001). "Muhasebe Eğitiminin İşletmelerin Taleplerini Karşılama Düzeyi: Türkiye Örneği”. ODTÜ Gelişme Dergisi. 28(3-4), ss. 281-310.

Eleren, A. - Kayahan, C.(2007). "Muhasebe Eğitiminin Öğrenci Bakış Açısıyla Değerlendirilmesi ve Afyon Kocatepe Üniversitesi Meslek Yüksekokullarında Bir Araştırma”. Muhasebe ve Denetime Bakış, Sayı 23 (Eylül), ss. 47-64.

Erol, M. - Erkan G. (2008). "Lisans Düzeyinde Muhasebe Eğitimi Alan Öğrencilerin Başarılarını Etkileyen Faktörlerin Belirlenmesine Yönelik Biga İktisadi ve İdari Birimler Fakültesinde Bir Araştırma”. KMU İ̈BF Dergisi Yı1:10 Sayı:14.

Gençtürk, M.- Bağcı, Y. (2005)., "Meslek Yüksekokulları ve Öğretim Elemanı Profili”. 3. Ulusal Meslek Yüksekokulları Sempozyumu, Eylül: 2005, ss. 22-31.

Gücenme, Ü.- Arsoy, A. P. (2006). “Accounting Education In The History Of Turkish Republic”. In Journal of Financial Analysis Special Issue Published by Istanbul Chamber of Certified Public Accountants for 17th World Congress of Accountants, pp. 13-16

International Federation of Accountants (IFAC). (2016). www.ifac.org (14.04.2016)

Ortar, M. (2017)., http://mustafaotrar.net/istatistik/dagilimlarin-normalligi-ve-normalligintest-edilmesi/ (Erişim Tarihi:25.03.2017)

Özdamar, K. (1999). "Paket Programlar İle İstatistiksel Veri Analizi”. Eskişehir: Kaan Kitabevi.

Sayın, K. Ş.- Tektüfekçi F. - Yeğinboy Y. (2005). “Dokuz Eylül Üniversitesi İ.İ.B.F’nde Öğretim Elemanlarının Bakış Açısıyla Muhasebe ve Finansman Eğitiminin Etkinliğinin Ölçülmesi ve Etkinliğin Artırılmasına Yönelik Çözüm Önerileri”. Muhasebe ve Finansman Dergisi 25 Ocak, ss.101-108.

Tazegül, A.- Karabayır, M. E. (2015). "Muhasebe Eğitim Standartlarının Lisans Eğitiminde Gerçekleşme Durumu: Öğrenci Kazanımları Değerlendirme Çalışması”. XXXIV. Türkiye Muhasebe Eğitimi Sempozyumu, ss.53-74.

Tavakol, M.,- Dennick, R. (2011). “Making Sense of Cronbach's Alpha”. International Journal of Medical Education, 2, pp. 53-55.

YOK, Yükseköğretim İstatistikleri 2017, https://istatistik.yok.gov.tr/ (25.03.2017)

Yücenurşen, M.- Bezirci, M.- Özpeynirci, R. - Peker, A. A. (2016). "Muhasebe Eğitimi ve Kalite Boyutları: Türkiye Alan Araştırması". Journal of Human Sciences, 13(1), ss.296-308. 